\title{
Evaluating Homeopathic Therapies for Contemporary Health Care: An Evident Priority
}

\author{
Vilelmine Carayanni
}

Additional information is available at the end of the chapter

http://dx.doi.org/10.5772/53016

\section{Introduction}

Health spending continues to rise faster than economic growth in most OECD countries, maintaining a trend observed since the 1970s. Health expenditure reached 9.5\% of GDP on the average in 2009 [1]. But the evolution of the health spending as a share of GDP is likely to stabilize or fall slightly in 2011. This is principally due to lowering health spending as governments seek to manage budget deficits. The economic evaluation has played a considerable role in this process in many countries such as the United Kingdom, the USA, Australia and Canada. Nevertheless, little attention has been given to the evaluation of complementary and alternative therapies, whereas their use has increased significantly in recent years: In the 2007 National Health Interview Survey (NHIS), in the USA, approximately 38 percent of adults reported using complementary and alternative medicine (CAM) in the previous 12 months. In the United States, patients are spending $\$ 34$ billion dollars (a significant amount of expenditure) on contemporary and alternative medications [2].Among the forms of alternative medication that have been of interest to all parties in the health sector is homeopathic medication. Having started in Germany over two centuries ago, homeopathic therapy has grown and spread over the years across Europe, America and the rest of the world. In most countries the government authorises, registers and supervises the health professionals. Regulations vary depending on the country. In some countries, there are no specific legal regulations concerning the use of homeopathy, while in others, licenses or degrees in conventional medicine from accredited universities are required [3]. Doctors of all specializations may without interrupting or altering chemical or any other therapy they prescribe to the patient, provide at the same time the homeopathic medicine of their choice, while the patient's organism will be benefited especially with immediate time sequence between demand and offer of help.

In many ways, homeopathic therapy is different from conventional medicine [2]. Generally, homeopathic therapy is based on the principle that suggests as follows: Materials that cause 
a living organism to experience certain conditions can be used to treat those particular conditions for which they cause the given symptoms. This particular principle has an ancient origin in the research of Hippocrates [4]. For example, quinine can be used to treat the condition of malaria [4]. Here, it is worth mentioning that the above principle is not similar with the mechanism of immune response in a living organism. The differences concerning the traditions as well as the production and the use between homeopathic and conventional medicines have direct implications on the cost as we will see in the next paragraphs. Since homeopathy is emerging as a possible complementary or even alternative to contemporary medication for the treatment of various conditions, more and more resources will continue to be spent on homeopathic therapies and on homeopathic research. So, an economic evaluation of homeopathic practice is therefore useful in the direction of understanding the economical viability of homeopathic practice [2].

\section{Homeopathic therapies: The beliefs of costs and effectiveness for homeopathic therapies}

\subsection{Efficacy: Does homeopathy work and how? Pre-clinical stage evidence}

It needs to be mentioned that homeopathic therapies have no molecule of an active ingredient per volume. Since many scientists have had a materialistic training, their scepticism about effectiveness is understandable.

At pharmacology's rational level, in 1988, the INSERM's immunologist J. Benveniste claimed that IgE antibodies have an effect on certain cell type after being diluted by a factor of 10 120[6]. A simple experiment by scientists and professors at the renown Aerospace Institute of the University of Stuttgart in Germany is confirming Dr. Jacques Benveniste's 1988 assertion that water has an imprint of energies to which it has been exposed [7]. Also, electrochemical studies have shown that there is a structural difference in the chemical and physical nature of diluted homeopathic carriers from controls [8,9].Nevertheless, these results must be verified by other studies.

Botanical science has also been helpful in evaluating the potential of homeopathy in treating organisms. Just like in other studies of homeopathy, modern scientists have been reluctant to follow up on incomplete literature that had been done by older generation scientists. Recently, two important observations have been made [8]. First, homeopathic substances were shown to slightly impact the health of healthy plants by just over $2 \%$. Here, although this particular impact was observed to be low, it was statistically consistent. In unhealthy plants, the impact of homeopathic substances rose to $20 \%$. Such observations have been in agreement with the notion that homeopathic substances (which are usually highly diluted to levels of zero molecules per volume) are more effective in sickly organisms than in healthy ones [4].

The effectiveness of homeopathic treatment has also been applied to animals. Here, it has been observed that an intoxication of an animal can be reversed by the use of relevant homeopathic remedies [10]. A meta-analysis of 105 intoxication trials showed clear, 
clinically relevant and significantly positive effects for homeopathic treatment [11,112] . Also, studies have suggested that highly diluted homeopathic treatments can replace missing substances in animals [13-15].

Nevertheless, according to some authors, despite these encouraging observational studies, the effectiveness of the homeopathic prevention or therapy of infections in veterinary medicine is not sufficiently supported by randomized and controlled trials [16]. There has also been a number of experiments which have suggested against the effectiveness of homeopathic treatments. For example, some rat experiments have brought to doubt the effectiveness of homeopathic substances in treating diseases [10]. However, since the positive results have been reproduced numerous times, some scientists are suggesting a pointer towards the efficacy of homeopathic substances.

\subsection{No better efficacy/ effectiveness than the placebo effect in clinical trials and safety questions}

In some human observations, people who were taking homeopathic treatment produced similar results from those that were taking controls; thus, suggesting that homeopathy is primarily a result of the placebo effect [17-20].Over 150 clinical trials have failed to show that homeopathy works and the effect of the homeopathic medicine is no better than the placebo effect. For example, in an experiment that was done in the UAE, a meta-analysis study of about 3500 patients showed a positive homeopathic response in 60 patients and a positive placebo response in 55 patients, thus, discrediting homeopathic treatment [4].When all the evidence from many trials is pooled together, homeopathy is no better than a placebo. Nevertheless, between 1950 and 2009, 142 R.C.T there have been published studies that examined a total number of 74 infections . 63 R.C.T. reported a positive result 68 R.C.T. did not produce any convincing proof and 11 RCT reported a negative result [21]. The Homeopathy Faculty in London recognized 24 census takings having positive results in: allergy, diarrhea in children, influenza, post operational ileus, rheumatologic infections, seasonal allergic rhinitis, infection of the upper respiratory ducts comprising otitis media [19].Some researches claimed that small-scale studies have yielded positive results, but this is due to poor methodologies or random effects [22].

We have to underline that according to all manuals of biostatistics medicine studies of phase III and afterward imply millions of persons and multiple centers in order to prove the "effectiveness" (and not any longer the "efficacy" of a therapy).This is not certainly the case for the majority of clinical trials published. In many fields much smaller unpowered samples predominate and studies quality according to Jadad scale is low[21,22].So, it seems that there is a generalized need to improve the quality of clinical studies and the problem does not concern only homeopathic therapies.

In the case of innocuousness, even in large samples, there may be harmful side effects where there is a very scant probability of appearance. Conversely to the notion of the mean effectiveness, innocuousness is mostly an individual affair. So we can understand the danger emerging by these small trials to approve the wrong treatment in many cases. Also, 
this specific outcome (innocuousness), is one of the main reasons of their preference acceptable even by the critics. The alcohol that is usually used in homeopathic drugs is $96^{\circ}$ that substantially evaporates and the information transmitted through water is only $4 \%$ so the probability to cause some reactions in patients is negligible. But even though the hazards from homeopathic products are modest in comparison with those of conventional medicines, the fast-growing popularity of homeopathy and its increasing use for selfmedication signify the need for continued vigilance to ensure the quality and safety of these products .

Beyond the above arguments mentioned, there are some other problems concerning the degree which homeopathic therapies may be adapted to the conventional RCT's scheme . Some of the reasons are that homeopathic therapies treat symptoms and not diagnosis, the therapies are mostly individualized. Also, instruments for the quality of life measurement do not comprise any items that measure the potential benefits of homeopathy as claimed by homeopaths including stess and control management and life attitude. Additionally, especially in explanatory oriented clinical studies, where the class of patients suitable for the trial is redefined a posteriori, patients proving unsuitable for any reason to follow allopathic treatment are excluded. That can produce selection bias in favor of the allopathic treatment.

\subsection{More costly than conventional medicine}

According to many opposites homeopathy is not only less effective but implies also a higher cost that is, conventional therapies are dominant therapies under the point of view of health economics. We will examine the different cost parameters to see the differences between homeopathic and allopathic medicines in such parameters.

1. Consultation costs. Unlike contemporary medicine, homeopathic treatment is more personalized. Before prescribing medications, homeopathic consultants will need to review one's emotional state, his health, among other factors in addition to disease symptoms. The above arrangement means that homeopathic practitioners are required to spend more hours with their patients when compared with contemporary health practitioners. A direct result of such an arrangement is high consultation costs in homeopathic practice. However, there is often a low follow up consultation cost. The initial high consultation cost is usually fruitful as most patients report better health; thus, a low follow up cost. Since many homeopathic practitioners will extensively evaluate issues that are often ignored by contemporary health practitioners, their patients usually report better health within a short time [25]. Another implication that is worth mentionning here is the necessity of specialist practitioners for patients who are under contemporary medications. Specialists usually charge high fees as compared to ordinary practitioners. Researches by Rossi et al. showed that patients under homeopathic medication were in less need of specialists as opposed to patients who were under contemporary medication [26]

2. Medication costs. Usually, homeopathic drugs are prepared by a process that thoroughly mixes active ingredients with a solvent through a vigorous shaking process. 
The process of diluting an active ingredient can be done for an infinite duration of time to obtain infinite quantities of medicine; thus resulting in homeopathic medications that have no molecule of an active ingredient per volume [2]. The economic implication of the above process is that homeopathic drugs can be prepared easily and at a low cost. Another factor that makes homeopathic drugs economical is the fact that homeopathic drugs are non-patented, generic, and can be easily reproduced. Consequently, costs that stem from copyright issues (among other costs that result from patented drugs) are eliminated. Also, as already mentioned homeopathy does not have the adverse events of conventional medicine implying additional costs. Also, a good part of homeopathic medicines according to homeopaths are preventive for some epidemic infections or contagious and they could assist to the better resistance against the prevention.

3. Diagnostic costs. Another factor that has helped to lower the cost of homeopathic medication as compared to ordinary medication is the lower requirement for laboratory procedures for patients that undergo homeopathic treatment as some studies indicated [25]. However, interpretation of these results are hampered due to the small sample size and the large variability between the practitioners.

\section{Homeopathy in different countries: Overal evaluations of cost effectiveness}

The high numbers of patients that are currently seeking homeopathic treatment in many countries suggest implications for health policy designers. More than a third of patients in the US that are suffering from allergy are seeking homeopathic treatment. [3].Among the countries that grant homeopathic therapies not of a lesser status we can site France, England, Germany, India, Bangladesh, the United States, Canada, Brazil, and many more. There has been a $60 \%$ growth in the homeopathic market in Europe over 10 years (19952005); from €590million to $€ 930$ million. $90 \%$ of homeopathic products are consumed by France, Germany, Netherlands, Spain, Belgium, UK and Poland [26]. Relative to population, France and Germany have highest consumption - 59\%-[27,28] More than half of the French declare that have already used homeopathic medicines, a number which constantly multiplies. (39\% in 2004, $53 \%$ in 2010). [29].In India, alternative treatments, including homeopathy, are well established and integrated into the healthcare system, with 94 per cent of people saying that they have faith in alternative remedies, and 62 per cent trusting homeopathy[28]. $15 \%$ of the population in Britain trust the homeopathy as a form of treatment [32].In Germany in 2006, homeopathic remedies accounted for 3.16\% of sold units ( $1.08 \%$ of business volume) in the pharmaceutical sector. $0.48 \%$ of prescriptions covered by public health insurance were for homeopathic remedies [33].

On the other hand, despite the extensive use of homeopathy few are the countries that reimburse homeopathic medicines. Some homeopathic treatment is covered by the national insurance of several European countries, including France, some parts of the United Kingdom, Denmark, and Luxembourg. In Austria, public insurance requires scientific proof of effectiveness in order to reimburse medical treatments, but exceptions are made for homeopathy[34]. In 2004, Germany which formerly offered homeopathy under its public 
health insurance scheme withdrew this privilege, with a few exceptions. In June 2005, the Swiss Government, after a 5-year trial, withdrew insurance coverage for homeopathy and four other complementary treatments, stating that they did not meet efficacy and costeffectiveness criteria. However, following the result of a referendum in 2009 the five therapies were reinstated for a further 6-year trial period starting from 2012[35].

In this section, we will study the existing estimation of how homeopathy is more or less costly, less or more effective at the global level of an economy and the related consequences on their reimbursement.

Nevertheless, full-scale economic evaluation of homeopathy is very difficult to take place because of organizational, financial and ethical reasons. Systematic reviews to conclude not only whether homeopathy works or harms, but also whether its adoption will lead to a more efficient use of resources are also very difficult to be undertaken due principally to the small number of existing studies by indication.

Some observational and quasi-experimental studies recorded the outcomes and costs of treatment by General Practitioners (GPs) who integrated homeopathy in their practice, compared with those who did not: Also, national reports (governmental, federal and health authorities reports) conclude on the economic viability of using homeopathic therapies at a national level by studying the cost and/or the effectiveness of homeopathic therapies. These reports with the exception of the 1991 French Government Report that uses observational data have the form of narrative reviews. We will briefly examine these reports.

\section{A. National reports and statements}

A 1991 French Government Report making use of observational data revealed a significantly reduced cost from homeopathic care versus conventional medical care [34]. The totality of costs associated with homeopathic care per physicians was approximately one-half of the total amount of care provided by conventional primary care physicians. However, because homeopathy physicians, on average, saw significantly fewer patients, the overall cost per patient under homeopathic care was still a significant $15 \%$ less. It is also interesting to note that these savings appear to increase the longer a physician has been using homeopathy [36].

The most complete governmental report is that of Switzerland [37]. Drawing cost data of participating physicians from Swiss health insurers, this review included all expenditures covered from consultation costs (diagnostic and therapeutic procedures), costs for medication (directly dispensed or prescriptions), costs for external laboratory analyses, and costs for physiotherapy.

The Swiss report found that total practice costs for physicians who specialized in homeopathic medicine had an overall 15.4 percent reduction in overall health care costs associated with their practice, as compared with physicians who practiced conventional medicine as well as those physicians who practice other "complementary and alternative medicine" treatments (but not homeopathic medicine). The report comprises a highlycomprehensive narrative review of the wide body of preclinical and clinical and conclude 
that effectiveness of homeopathy can be supported by clinical evidence and professional and adequate application regarded as safe. Reliable statements of cost-effectiveness are not available at the moment, but the report states that cost- effectiveness studies on individual complementary medical treatments clearly indicate possible savings.

The Federal Centre of Expertise in Health Care (KCE)of Belgium has edited an analytical report, the second more completed national report based on narrative review[38] . This report concludes that the fees are higher than the other three non-conventional medical. This conclusion is based exclusively on cost data selected by secondary sources (patients) . Nevertheless, published economic evaluations are excluded from the review undertaken by this report .From a purely clinical perspective, by reviewing 26 systematic reviews, this report concludes that there is no evidence of the efficacy of homeopathy (evidence-based medicine) beyond the placebo effect. Nevertheless, it is not clear as to the exact exclusion criteria that concluded in 26 reviews having initially selected 80 studies retrieved for more detailed evaluation.

A national overview of homeopathy and other CAM therapies conclude for a significant improvement in health outcomes and after treatment an increase in days off work [39,37].

Beyond these reports no other reports use cost and effectiveness criteria to conclude about the economic viability of the homeopathic therapies. Recently, the House of Commons Science and Technology Committee advised that NHS funding should be stopped "since effectiveness of homeopathic medicines has not been proved superior than placebo effect"[40]. Despite this report, the Coalition stated homeopathy would continue to be funded, with PCTs responsible for making decisions locally.

The specific report followed a public statement by the National Health and Medical Research Council (NHMRC) attesting as a basic source the English report and is of the opinion that there is sufficient scientific evidence to conclude that homeopathy is no more efficacious than placebo [41]. We are not aware of any other national report or statement at this time.

Canada on the other hand (Canada Health, Ottawa) has established a research program with priority to the cost effectiveness evaluation for the natural products of health care such homeopathic medicines since it is stated that "the results of an important number of metaanalyses permits a cautious optimism [42].

\section{B. Observational and quasi- experimental studies of the overall cost and effectiveness}

A 1996 study of 130,000 prescriptions confirmed the results of the 1991 French government report (see above) and suggested significant benefits and savings as a result of homeopathic treatment. This survey also noted that the number of paid sick leave days by patients under the care of homeopathic physicians were 3.5 times less (598 days/year) than patients under the care of general practitioners (2,017 days/year). These figures suggest further benefit and savings to the homeopathic approach to care [43]. 
Smallwood's report included a study by Swayne et al. published in 1992 which examined the prescription costs of 22 doctors in the UK found that practices which included a GP using homeopathy prescribed $12 \%$ fewer items of medication per patient (including both conventional drugs and homeopathic medicines) compared with other local practices. Smallwood calculates that if this figure was extrapolated to a national level the number of items prescribed would be reduced by 41.5 million $[44,45)$.

In Belgium, Wassenhoven and Yves studied 782 patients (most of who had serious conditions) who were undergoing homeopathic medication [25].

The findings of Wassenhoven and Yves suggest that ordinary doctors spend as much as three times on drugs as compared to their homeopathic counterparts. On the other hand, homeopathic doctors spend only a fifth of what is spent by contemporary doctors on antibiotics. Such a direction indicates massive savings (about 800 million Euros) that can be made if all doctors in Belgium were to prescribe medicines as homeopathic practitioners [25]

Further details for all these studies as well as for other cost studies are given in Bornhöft et al [37].Nevertheless, results of these studies have to be assessed with some caution because of some methodological limitations concerning especially their design and need of research to confirm the above mentioned results .

To conclude, in relatively few countries systematic efforts have been undertaken to estimate the cost and effectiveness of homeopathy at a national level despite its extensive use. Health Technology assessments are few and do not proceed to a systematic review of costeffectiveness since the number of these studies by morbidity is too small. Observational and quasi experimental studies is well known that do not conveniently ensure the comparability of the groups. An attempt to understand the full economic impact of homeopathic practice at a macro scale level would have to consider an array of factors that are difficult to analyze (e.g consequences on the employment in the manufacturing sector). These are issues that are difficult to evaluate. The work of many researchers on the above issue can only be used to lay ground for a more detailed and exhaustive research. The evaluation of quality of life of the citizens by using adapted quality of life questionnaires and the avoidance at national level of adverse events by using homeopathy constitute central points for future research.

\section{Cost and effectiveness of homeopathy by indication: A critical review of economic evaluation studies}

\section{Methods}

For the assessment of the trial based economic evaluations we have used the International Society of Pharmacoeconomics and Outcomes Research (ISPOR) RCT CEA Task Force Report. For the other types of studies as well as for the global assessment and their comparison with studies of conventional medicine, we have used BMJ guidelines [47]. We have compared also these results with results from systematic reviews in conventional medicine [48,49]. 
More analytically, the results of a review [49] of conventional medicine have been used as well as the reviews for some studies of the Centre for Reviews and Dissemination of the University of York [51] that have been completed by the author in order to compare the criteria completion between homeopathic and conventional medicine in the case of Trial Based Economic Evaluations. As there are not yet specific guidelines for economic evaluations based on observational studies, items from the BMJ Checklist have been additionally used to make possible the assessment of all studies. The results of a review [49] of conventional medicine studies have been used and completed in order to compare statistically the criteria completion between homeopathic [53,66-70] and conventional medicine studies [71-79]. We have completed this review by Centre for Review and Dissemination Reviews for some studies [50] as well as by author review.

We have selected only full economic evaluations for our review focusing on special indications. Full economic evaluations compare at least 2 different strategies and measure both costs and health results (cost effectiveness/cost consequences, cost utility and cost benefit).Cost-benefit analysis attempt to value the consequences of programs in money terms [50]. The cost effectiveness analysis in its classical form, considers a single measure of output and the results are presented in the form of a cost effectiveness ratio. An other version of the cost effectiveness analysis, the cost consequences analysis presents an array of output measures alongside costs without aggregation. In the cost utility analysis the consequences are adjusted by health state preference scores [50].

\section{Research strategy}

We researched the following electronic databases from January 1999 to January 2012: DARE, NHS EED and HTA Medline, EMBASE, AMED, Alt-Health-Watch, and the Complementary and Alternative Medicine Citation Index via NCCAM and the National Library of Medicine (NLM). Researching has been restricted to English, French and Greek language journals and human studies with the keywords: homeopathy, and costs or cost analysis or cost-benefit, or cost-effective or cost utility economic analysis, or economic evaluation.

\section{Data analysis}

Because of too small sample size of studies selected, in the case of Trial Based Economic Evaluations no statistical test has been used to detect any differences between homeopathic and conventional medicine studies on the completion of the above mentioned criteria. For the assessment of all economic evaluations based on BMJ Checklist, Fisher's exact mid-p test has been used to test the homogeneity between the 2 groups for each quality criteria as well as for the total of the quality criteria. Fisher's exact mid-p test is the mid- $p$ version of Fisher's exact conditional test, only half the probability of the observed outcome is included in the mid-p-value [80]. The resulting test is less conservative than Fisher's exact test, and its performance approximates that of an unconditional test. For the statistical analysis $\mathrm{R}$ software has been used [81].

\section{Results}

We have detected 186 records as well as 3 additional records identified by other sources (University of Lyon I). 80 duplicates have been detected and deleted. 25 full text articles have 
been detected and selected for eligibility (Figure 1) [82]. Eight of these publications met the criteria of full economic evaluations, whereas the others were partial economic evaluations and/ or did not focus on special indications. One of these publications comprises a randomized trial, an observational study and a review that we will study separately. So we will study 10 studies in the total comparing homeopathy with conventional medicine. Three of these studies were randomized clinical trials, 3 observational studies and one study was a review.

\section{Trials based economic evaluations review}

Details of the 3 studies [52-54] comparing homeopathy with conventional medicine [55-62] are given below (Table 1).

\begin{tabular}{|c|c|c|c|c|c|}
\hline $\begin{array}{l}\text { Authors, } \\
\text { country and } \\
\text { year of } \\
\text { publication }\end{array}$ & Indication & $\begin{array}{l}\text { Type of } \\
\text { economic } \\
\text { evaluation }\end{array}$ & Patients groups & $\begin{array}{l}\text { Health Effects } \\
\text { of } \\
\text { Homeopathy } \\
\text { compared to } \\
\text { Conventional } \\
\text { medicine }\end{array}$ & $\begin{array}{l}\text { Cost of } \\
\text { Homeopathy } \\
\text { compared to } \\
\text { Conventional } \\
\text { medicine }\end{array}$ \\
\hline $\begin{array}{l}\text { Paterson et al, } \\
\text { (2003),United } \\
\text { Kingdom[52] }\end{array}$ & Dyspepsia & $\begin{array}{l}\text { Cost } \\
\text { effectiveness }\end{array}$ & $\begin{array}{l}\text { a. acupuncture } \\
\text { b. Homeopathy } \\
\text { c. normal GP } \\
\text { care }\end{array}$ & $\begin{array}{l}\text { No significant } \\
\text { differences } \\
(a=5 \%)\end{array}$ & $\begin{array}{l}\text { No significant } \\
\text { differences } \\
(a=5 \%)\end{array}$ \\
\hline $\begin{array}{l}\text { Kneis and } \\
\text { Gandjour,2009, } \\
\text { Germany[53] }\end{array}$ & $\begin{array}{l}\text { Acute } \\
\text { Maxillary } \\
\text { Sinusitis }\end{array}$ & Cost utility & $\begin{array}{l}\text { a. Homeopathy } \\
\text { b. Placebo (no } \\
\text { active treatment) }\end{array}$ & $\begin{array}{l}\text { Significant } \\
\text { differences in } \\
\text { favor of } \\
\text { homeopathy } \\
(a=5 \%)\end{array}$ & $\begin{array}{l}\text { Significant } \\
\text { differences in } \\
\text { favor of } \\
\text { homeopathy } \\
(a=5 \%)\end{array}$ \\
\hline $\begin{array}{l}\text { Thompson et } \\
\text { al, 2011,United } \\
\text { Kingdom[54] }\end{array}$ & Asthma & $\begin{array}{l}\text { Cost } \\
\text { effectiveness }\end{array}$ & $\begin{array}{l}\text { a. Homeopathic } \\
\text { treatment } \\
\text { b. Usual care }\end{array}$ & $\begin{array}{l}\text { No significant } \\
\text { differences } \\
(a=5 \%)\end{array}$ & $\begin{array}{l}\text { No significant } \\
\text { differences } \\
(a=5 \%)\end{array}$ \\
\hline
\end{tabular}

Table 1. Trial Based Economic Evaluations comparing homeopathy with conventional medicine

Table 2 presents the results of the review. As can be seen, no important deviation has been observed between homeopathic and conventional medicine studies. All studies comparing homeopathy with conventional therapy (100\%) are pragmatically oriented to measure the effectiveness versus efficacy with some stricter criteria for inclusion in the third study reasonable for this type of intervention (criterion1). Also, 5 out of $8(63 \%)$ of conventional studies seem to follow a more pragmatic design oriented to measure effectiveness rather than efficacy despite the stricter inclusion criteria of 4 out of 8 studies of conventional medicine. Three of these studies are considered as more explanatory [63] since they do not use Intention to Treat Approach although this approach in recent years has almost universally dominated [64]. 


\begin{tabular}{|c|c|c|}
\hline ISPOR's criteria[46] & $\begin{array}{c}\text { Review of } \\
\text { homeopathic } \\
\text { medicines studies } \\
\text { N (\%) }\end{array}$ & $\begin{array}{l}\text { Reviews of } \\
\text { conventional } \\
\text { studies } \\
\text { N (\%) }\end{array}$ \\
\hline \multicolumn{3}{|l|}{ A. Clinical trial design } \\
\hline $\begin{array}{l}\text { 1.Trial design should reflect effectiveness rather than } \\
\text { efficacy when possible }\end{array}$ & $3(100)$ & $8(63)$ \\
\hline 2. Full follow-up of all patients is encouraged. & $3(100)$ & $8(75)^{*}$ \\
\hline $\begin{array}{l}\text { 3. Describe power and ability to test hypotheses, given } \\
\text { the trial sample size. }\end{array}$ & $3(0)$ & $8(25)$ \\
\hline $\begin{array}{l}\text { 4. Clinical end points used in economic evaluations } \\
\text { should be disaggregated }\end{array}$ & $3(100)$ & $8(100)$ \\
\hline $\begin{array}{l}\text { 5. Direct measures of outcome are preferred to use of } \\
\text { intermediate end points. }\end{array}$ & $3(100)$ & $8(100)$ \\
\hline \multicolumn{3}{|l|}{ B. Data elements } \\
\hline $\begin{array}{l}\text { 6. Obtain information to derive health state utilities } \\
\text { directly from the study population }\end{array}$ & $2(50)$ & $8(80)$ \\
\hline $\begin{array}{l}\text { 7. Collect all resources that may substantially influence } \\
\text { overall costs; these include those related and unrelated } \\
\text { to the intervention }\end{array}$ & $2(33)$ & $8(38)$ \\
\hline \multicolumn{3}{|l|}{ C. Database design and management } \\
\hline $\begin{array}{l}\text { 8. Collection and management of the economic data } \\
\text { should be fully integrated into the clinical data. }\end{array}$ & $3(100)$ & $8(63)$ \\
\hline $\begin{array}{l}\text { 9. Consent forms should include wording permitting the } \\
\text { collection of economic data, particularly when it will be } \\
\text { gathered from third-party databases and may include } \\
\text { pre- and/or post-trial records }\end{array}$ & $3(0)$ & $8(0)$ \\
\hline \multicolumn{3}{|l|}{ D. Analysis } \\
\hline $\begin{array}{l}\text { 10. The analysis of economic measures should be guided } \\
\text { by a data analysis plan and hypotheses that are drafted } \\
\text { prior to the onset of the study }\end{array}$ & $3(0)$ & $8(0)$ \\
\hline 11.1 Intention-to-treat analysis & $3(100)$ & $8(63)^{*}$ \\
\hline $\begin{array}{l}\text { 11.2 Common time horizon(s) for accumulating costs } \\
\text { and outcomes }\end{array}$ & $3(100)$ & $8(75)$ \\
\hline 11.3 Within-trial assessment of costs and outcomes & $3(100)$ & $8(100)$ \\
\hline $\begin{array}{l}\text { 11.4 Assessment of uncertainty is necessary for each } \\
\text { measure }\end{array}$ & $3(0)$ & $8(13)$ \\
\hline
\end{tabular}




\begin{tabular}{|c|c|c|}
\hline ISPOR's criteria[46] & $\begin{array}{c}\text { Review of } \\
\text { homeopathic } \\
\text { medicines studies } \\
\text { N (\%) }\end{array}$ & $\begin{array}{l}\text { Reviews of } \\
\text { conventional } \\
\text { studies } \\
\text { N (\%) }\end{array}$ \\
\hline $\begin{array}{l}\text { 11.5 Common discount rate applied to future costs } \\
\text { and outcomes }\end{array}$ & $\mathrm{NA}^{* *}$ & NA \\
\hline 11.6 An accounting for missing and/or censored data & $3(75)$ & $8(100)$ \\
\hline $\begin{array}{l}\text { 12. Incremental costs and outcomes should be measured } \\
\text { as differences in arithmetic means, with statistical } \\
\text { testing accounting for issues specific to these data }\end{array}$ & $3(33)$ & $8(13)$ \\
\hline $\begin{array}{l}\text { 13. One or more summary measures should be used to } \\
\text { characterize the relative value of the intervention }\end{array}$ & $3(33)$ & $8(63)$ \\
\hline 14.1 Sampling uncertainty accounting & $1(100)$ & $8(63)^{*}$ \\
\hline 14.2 Parameter uncertainty accounting & $3(33)$ & $8(38)$ \\
\hline $\begin{array}{l}\text { 14.3 Protocol-driven resource use are addressed (in the } \\
\text { design phase) }\end{array}$ & $3(3)$ & $8(13)$ \\
\hline 14.3 Unrepresentative recruiting centers are addressed & $3(100)$ & $8(100)$ \\
\hline $\begin{array}{l}14.4 \text { Inclusion of study sites from countries with varying } \\
\text { access and availability of health-care services is addressed }\end{array}$ & $3(0)$ & $8(0)$ \\
\hline $\begin{array}{l}\text { 14.5 Restrictive inclusion and exclusion criteria are } \\
\text { addressed }\end{array}$ & $3(100)$ & $8(63)$ \\
\hline 14.6 Artificially enhanced compliance is addressed & $3(100)$ & $8(75)$ \\
\hline $\begin{array}{l}\text { 15. Multinational trials require special consideration to } \\
\text { address inter-country differences in population } \\
\text { characteristics and treatment patterns }\end{array}$ & $\mathrm{NA}^{* *}$ & $1(0)$ \\
\hline $\begin{array}{l}\text { 16. When models are used to estimate costs and } \\
\text { outcomes beyond the time horizon of the trial, good } \\
\text { modeling practices should be followed.. }\end{array}$ & NA & NA \\
\hline $\begin{array}{l}\text { 17. Models should reflect the expected duration of the } \\
\text { intervention on costs and outcomes. }\end{array}$ & NA & NA \\
\hline 18. Subgroup analyses (ex post) are encouraged & NA & NA \\
\hline \multicolumn{3}{|l|}{ E. Reporting the results } \\
\hline 19. Patient demographics are reported & $3(100)$ & $8(63)$ \\
\hline 20. Trial setting is reported & $3(100)$ & $8(100)$ \\
\hline $\begin{array}{l}\text { 21. Inclusion and } \\
\text { exclusion criteria are reported }\end{array}$ & $3(100)$ & $8(100)$ \\
\hline
\end{tabular}




\begin{tabular}{|c|c|c|}
\hline ISPOR's criteria[46] & \begin{tabular}{|c|} 
Review of \\
homeopathic \\
medicines studies \\
N (\%)
\end{tabular} & $\begin{array}{c}\text { Reviews of } \\
\text { conventional } \\
\text { studies } \\
\text { N (\%) }\end{array}$ \\
\hline $\begin{array}{l}\text { 22. Protocol-driven procedures } \\
\text { that influence external validity are reported }\end{array}$ & $3(0)$ & $8(13)$ \\
\hline $\begin{array}{l}\text { 23. Intervention } \\
\text { and control arms are reported }\end{array}$ & $3(100)$ & $8(100)$ \\
\hline $\begin{array}{l}\text { 24. Time horizon for the } \\
\text { intervention and follow-up are reported. }\end{array}$ & $3(100)$ & $8(100)$ \\
\hline 25. Key clinical findings are reported & $3(100)$ & $8(100)$ \\
\hline $\begin{array}{l}\text { 26. Reporting should distinguish economic data } \\
\text { collected as part of the trial vs. data not collected as part } \\
\text { of the trial }\end{array}$ & $3(100)$ & $8(100)$ \\
\hline 27. Amount of missing and censored data & $3(67)$ & $8(63)^{*}$ \\
\hline $\begin{array}{l}\text { 28. If imputation methods are used, the method should } \\
\text { be described. }\end{array}$ & $1(100)$ & $2(100)^{*}$ \\
\hline $\begin{array}{l}\text { 29. Methods used to construct and compare costs and } \\
\text { outcomes, and to project costs and outcomes beyond the } \\
\text { trial period should be described. }\end{array}$ & $3(100)$ & $8(75)$ \\
\hline $\begin{array}{l}\text { 30. The results section should include summaries of } \\
\text { resource use, costs, and outcome measures, including } \\
\text { point estimates and measures of } \\
\text { uncertainty }\end{array}$ & $3(0)$ & $8(0)$ \\
\hline $\begin{array}{l}\text { 31. Results should be reported for the time horizon of } \\
\text { the trial (and for projections) }\end{array}$ & $3(100)$ & $8(100)$ \\
\hline $\begin{array}{l}\text { 32. Graphical displays are recommended for results not } \\
\text { easily reported in tabular form }\end{array}$ & $1(100)$ & $6(33)$ \\
\hline
\end{tabular}

* Comparable estimates available from Polsky et al, 2006

** Not appropriate

Table 2. ISPOR's Good Research Practices

Power calculations, (criterion 3), were not performed in the planning phase of the study in none of the studies.( $0 \%$ ) treating homeopathy (however, power calculations were performed retrospectively in the first study [52].

One out of the three studies (33\%) of homeopathy and 3 out of $8(38 \%)$ of the studies of conventional medicine have measured some additional costs (criterion 7) beyond direct health costs. 
None of the homeopathy (0/3) and conventional medicine studies (0/8) include in the consent form wording permitting for economic data collection (although in the study of Thompson et al [54] cost data are collected by children's parents.

None of the homeopathy $(0 \%)$ or conventional medicine studies $(0 \%)$ establish the hypotheses with a data analysis plan (criterion 10). No discount rate has been applied, (criterion 11.5), as the study period for each participant was 1 year in all studies.

Whereas all homeopathic medicine studies use p- values for hypotheses tests $(100 \%)$, and respectively 6 out of 8 conventional medicine studies (75\%), only one conventional medicine study reports confidence intervals for point estimates of all measures (criterion 11.4) and none homeopathic study.

Sensitivity analysis (criterion 14.2) has been used by the one of the three homeopathic studies (33\%) whereas 3/8 conventional studies (38\%) use sensitivity analysis for costs and outcomes. All homeopathic studies $(100 \%)$ and 7 out of 8 of conventional studies $(88 \%)$, have been well addressed by the design the protocol induced procedures except one study of conventional medicine (criterion 14.3) . Nevertheless, in the report of results (criterion 23), there is no mention made in homeopathic studies $(0 \%)$ concerning them as to whether there were observed and addressed or not except for one study of conventional medicine $(13 \%)$ to which they have been spotted and measured).

Finally, the 2 categories of studies present proportional weakness and strengths with the biggest differences in favor of conventional medicine focused on aggregated outcomes (2/3 trials of homeopathy use cost consequences analyses). The trial based economic evaluations comparing homeopathy with conventional medicine do not seem to be of lower quality than studies of conventional medicine and complete the majority of the ISPOR's criteria. Also, homeopathy clinical trials are for some aspects more adapted to the traditional clinical trials guidelines offering better information on patient characteristics and flow [65].Additionally they avoid some aspects of explanatory design a more pragmatic design such as stricter eligibility criteria and no intention to treat approach. Nevertheless, no definitive conclusions can be extracted because of the too small sample sizes.

\subsection{BMJ checklist including all full economic evaluations}

Information for homeopathic studies included in this review is given on Table 3.The quality of homeopathic economic evaluation studies seems to constantly progress given that more recent studies are characterized by an improved design and more detailed reports, as is the case with conventional studies [4]. As can be seen,(Table 4), a significantly superior number of homeopathic studies defines clearly the aspect of the economic evaluation (criterion 3 ). Also, details of the subjects from which values were obtained are given more frequently by homeopathic studies (criterion 13). On the other hand, conventional studies use more frequently sensitivity analyses (criterion 27) as well as incremental analyses and aggregate clinical outcomes (criteria 31 and 32), as the majority of homeopathic studies included use cost consequences analyses (80\%).Finally, both categories of studies present deficiencies 
concerning the justification of the form of economic evaluation chosen. The overall percentage of studies that complete BMJ criteria is $70.6 \%$ for homeopathic studies and $78.6 \%$ for conventional studies. By the mid- $p$ version of Fisher's exact conditional test we conclude that the differences observed between the 2 groups of studies aren't statistically significant. (mid p-value=0.20). Consequently, we accept the homogeneity between homeopathic and conventional medicine studies on the BMJ guidelines completion.

\begin{tabular}{|c|c|c|c|c|c|}
\hline $\begin{array}{c}\text { Authors year } \\
\text { of publication } \\
\text { and country }\end{array}$ & $\begin{array}{l}\text { Morbidity } \\
\text { studied }\end{array}$ & $\begin{array}{c}\text { Type of } \\
\text { economic } \\
\text { evaluation }\end{array}$ & $\begin{array}{l}\text { Patients } \\
\text { groups }\end{array}$ & $\begin{array}{c}\text { Cost of } \\
\text { Homeopathy } \\
\text { versus } \\
\text { conventional } \\
\text { medicine }\end{array}$ & $\begin{array}{c}\text { Health Effects } \\
\text { of } \\
\text { Homeopathy } \\
\text { versus } \\
\text { conventional } \\
\text { medicine }\end{array}$ \\
\hline $\begin{array}{l}\text { Stagnara et al, } \\
(2004), \\
\text { France [66] }\end{array}$ & $\begin{array}{l}\text { Bronchiolitis } \\
\text { (neonatal) }\end{array}$ & $\begin{array}{l}\text { Cost } \\
\text { effectiveness }\end{array}$ & $\begin{array}{l}\text { a. Homeopathy } \\
\text { b. usual care }\end{array}$ & $\begin{array}{l}\text { Significant } \\
\text { differences } \\
(a=5 \%) \\
\text { Less costly }\end{array}$ & $\begin{array}{l}\text { significant } \\
\text { differences } \\
(a=5 \%) \\
\text { More effective }\end{array}$ \\
\hline $\begin{array}{l}\text { Veinchtock et } \\
\text { al, (2000) } \\
\text { France [67] }\end{array}$ & $\begin{array}{l}\text { Anxiety } \\
\text { disorders }\end{array}$ & $\begin{array}{l}\text { Cost } \\
\text { consequences }\end{array}$ & $\begin{array}{l}\text { a. Homeopathy } \\
\text { b. Usual care }\end{array}$ & $\begin{array}{l}\text { No significant } \\
\text { differences } \\
(\mathrm{a}=5 \%)\end{array}$ & $\begin{array}{l}\text { No significant } \\
\text { differences } \\
(\mathrm{a}=5 \%)\end{array}$ \\
\hline $\begin{array}{l}\text { Trichard et al, } \\
\text { 2005, } \\
\text { France [68] }\end{array}$ & $\begin{array}{l}\text { Acute } \\
\text { Rhino- } \\
\text { pharyngitis } \\
\text { (Children) }\end{array}$ & $\begin{array}{l}\text { Cost } \\
\text { effectiveness }\end{array}$ & $\begin{array}{l}\text { a. Homeopathy } \\
\text { b. Usual care }\end{array}$ & $\begin{array}{l}\text { Significant } \\
\text { differences } \\
(a=5 \%) \\
\text { Less costly }\end{array}$ & $\begin{array}{l}\text { Significant } \\
\text { differences } \\
(a=5 \%) \\
\text { More effective }\end{array}$ \\
\hline $\begin{array}{l}\text { Witt et al, 2005, } \\
\text { Germany [69] }\end{array}$ & $\begin{array}{l}\text { Headache } \\
\text { Low back pain } \\
\text { Depression } \\
\text { Insomnia }\end{array}$ & $\begin{array}{l}\text { Cost } \\
\text { effectiveness }\end{array}$ & $\begin{array}{l}\text { a. Homeopathy } \\
\text { b. usual care }\end{array}$ & $\begin{array}{l}\text { No significant } \\
\text { differences } \\
(a=5 \%)\end{array}$ & $\begin{array}{l}\text { Significant } \\
\text { differences } \\
(a=5 \%) \\
\text { More effective }\end{array}$ \\
\hline $\begin{array}{l}\text { Witt et al, 2009, } \\
\text { Germany [70] }\end{array}$ & $\begin{array}{l}\text { atopic eczema } \\
\text { (children) }\end{array}$ & $\begin{array}{l}\text { Cost } \\
\text { effectiveness }\end{array}$ & $\begin{array}{l}\text { a. Homeopathy } \\
\text { b. Usual care }\end{array}$ & $\begin{array}{l}\text { Significant } \\
\text { differences } \\
(a=5 \%) \\
\text { More costly }\end{array}$ & $\begin{array}{l}\text { No significant } \\
\text { differences } \\
(a=5 \%)\end{array}$ \\
\hline $\begin{array}{l}\text { Kneis and } \\
\text { Gandjour, } \\
\text { 2009, } \\
\text { Germany [53] }\end{array}$ & $\begin{array}{l}\text { Acute } \\
\text { Maxillary } \\
\text { Sinusitis }\end{array}$ & Cost utility & $\begin{array}{l}\text { a. Homeopathy } \\
\text { b. Placebo }\end{array}$ & $\begin{array}{l}\text { Significant } \\
\text { differences } \\
(a=5 \%) \\
\text { Less costly }\end{array}$ & $\begin{array}{l}\text { Significant } \\
\text { differences } \\
(a=5 \%) \\
\text { More effective }\end{array}$ \\
\hline $\begin{array}{l}\text { Kneis and } \\
\text { Gandjour, } 2009 \\
{[53]}\end{array}$ & $\begin{array}{l}\text { Acute } \\
\text { Maxillary } \\
\text { Sinusitis }\end{array}$ & $\begin{array}{l}\text { Cost } \\
\text { effectiveness }\end{array}$ & $\begin{array}{l}\text { a. Homeopathy } \\
\text { b. } \\
\text { Antibacterials }\end{array}$ & Less costly & $\begin{array}{l}\text { Significant } \\
\text { differences in } \\
\text { favor of } \\
\text { homeopathy }\end{array}$ \\
\hline
\end{tabular}

Table 3. Non randomized studies for homeopathic treatment 


\begin{tabular}{|c|c|c|c|}
\hline Items from the BMJ Checklist [47] & $\begin{array}{c}\text { Review of } \\
\text { homeopathic } \\
\text { medicines } \\
\text { studies N(\%) }\end{array}$ & $\begin{array}{c}\text { Reviews of } \\
\text { conventional } \\
\text { studies } \\
\mathrm{N}(\%)\end{array}$ & $\begin{array}{l}\text { Mid } p- \\
\text { value }\end{array}$ \\
\hline \multicolumn{4}{|l|}{ Study design } \\
\hline 1.The research question is stated & $10(100)$ & $9(100)$ & 0.5 \\
\hline $\begin{array}{l}\text { 2. The economic importance of the research } \\
\text { question is stated }\end{array}$ & $10(80)$ & $9(78)$ & 0.5 \\
\hline 3. The perspective of the analysis is stated & $10(100)$ & $9(67)^{*}$ & 0.04 \\
\hline $\begin{array}{l}\text { 4. The rationale for choosing the } \\
\text { alternatives is stated }\end{array}$ & $10(90)$ & $9(100)$ & 0.5 \\
\hline $\begin{array}{l}\text { 5. The alternatives being compared are } \\
\text { clearly described }\end{array}$ & $10(90)$ & $9(100)$ & 0.5 \\
\hline $\begin{array}{l}\text { 6. The form of economic evaluation used is } \\
\text { stated }\end{array}$ & $10(50)$ & $9(89)$ & 0.07 \\
\hline $\begin{array}{l}\text { 7. The choice of form of economic } \\
\text { evaluation is justified }\end{array}$ & $10(0)$ & $9(11)$ & 0.09 \\
\hline \multicolumn{4}{|l|}{ Data collection } \\
\hline $\begin{array}{l}\text { 8. The source(s) of effectiveness estimates } \\
\text { are stated }\end{array}$ & $10(100)$ & $9(100)$ & 0.5 \\
\hline $\begin{array}{l}\text { 9. Details of the effectiveness study are } \\
\text { given }\end{array}$ & $10(100)$ & $9(100)$ & 0.5 \\
\hline $\begin{array}{l}\text { 10. Primary outcome measures are clearly } \\
\text { stated }\end{array}$ & $10(90)$ & $9(89)$ & 0.5 \\
\hline $\begin{array}{l}\text { 11. Methods to value health states are } \\
\text { stated }\end{array}$ & $6(100)$ & $9(89)^{*}$ & 0.5 \\
\hline $\begin{array}{l}\text { 12. Details of the method of synthesis or } \\
\text { meta-analysis of estimates are given }\end{array}$ & $1(100)$ & $5(20)$ & - \\
\hline $\begin{array}{l}\text { 13. Details of the subjects from which } \\
\text { values were obtained are given }\end{array}$ & $6(100)$ & $9(56)$ & 0.05 \\
\hline $\begin{array}{l}\text { 14. Productivity changes are reported } \\
\text { separately }\end{array}$ & $10(60)$ & $9(44)$ & 0.33 \\
\hline $\begin{array}{l}\text { 15. The relevance of productivity changes is } \\
\text { discussed }\end{array}$ & $10(20)$ & $9(33)$ & 0.31 \\
\hline $\begin{array}{l}\text { 16. Quantities of resources are reported } \\
\text { separately from unit costs }\end{array}$ & $10(70)$ & $9(78)$ & 0.5 \\
\hline $\begin{array}{l}\text { 17. Methods for the estimation of quantities } \\
\text { and unit costs are described }\end{array}$ & $10(100)$ & $9(100 \mid$ & 0.5 \\
\hline
\end{tabular}




\begin{tabular}{|c|c|c|c|}
\hline Items from the BMJ Checklist [47] & $\begin{array}{c}\text { Review of } \\
\text { homeopathic } \\
\text { medicines } \\
\text { studies N(\%) }\end{array}$ & $\begin{array}{c}\text { Reviews of } \\
\text { conventional } \\
\text { studies } \\
\mathrm{N}(\%) \\
\end{array}$ & $\begin{array}{l}\text { Mid } p- \\
\text { value }\end{array}$ \\
\hline $\begin{array}{l}\text { 18. The currency and price date should be } \\
\text { recorded }\end{array}$ & $10(90)$ & $9(89)$ & 0.5 \\
\hline $\begin{array}{l}\text { 19. Details of any adjustment for inflation, } \\
\text { or currency conversion are given }\end{array}$ & NA & $3(75)$ & - \\
\hline 20. Details of any model used are given & $\mathrm{NA}^{* *}$ & $6(100)$ & - \\
\hline $\begin{array}{l}\text { 21. The choice of the model and its key } \\
\text { parameters are justified }\end{array}$ & NA & $6(33)$ & - \\
\hline \multicolumn{4}{|l|}{ Analysis and interpretation of results } \\
\hline $\begin{array}{l}\text { 22. Time horizon of costs and benefits is } \\
\text { stated }\end{array}$ & $10(100)$ & $9(100)$ & 0.5 \\
\hline 23. The discount rate is stated & NA & $6(86)$ & - \\
\hline 24. The choice of discount rate is justified & NA & $6(33)$ & - \\
\hline $\begin{array}{l}\text { 25. An explanation is given if costs and } \\
\text { benefits not discounted }\end{array}$ & $10(30)$ & $3(0)$ & 0.5 \\
\hline $\begin{array}{l}\text { 26. Details of statistical tests and confidence } \\
\text { intervals are given for stochastic data }\end{array}$ & $9(56)$ & $3(67)$ & 0.5 \\
\hline $\begin{array}{l}\text { 27. The approach to sensitivity analysis is } \\
\text { given }\end{array}$ & $10(40)$ & $9(89)^{*}$ & 0.03 \\
\hline $\begin{array}{l}\text { 28. The choice of variables for sensitivity } \\
\text { analysis is justified }\end{array}$ & $10(40)$ & $9(67)$ & 0.21 \\
\hline $\begin{array}{l}\text { 29. The ranges over which variables are } \\
\text { varied are stated }\end{array}$ & $10(40)$ & $9(78)$ & 0.08 \\
\hline 30. Relevant alternatives are compared & $10(100)$ & $9(100)$ & 0.5 \\
\hline 31. Incremental analysis is reported & $10(20)$ & $9(89)$ & 0.003 \\
\hline $\begin{array}{l}\text { 32. Major outcomes are presented } \\
\text { disaggregated and aggregated }\end{array}$ & $10(20)$ & $9(89)$ & 0.003 \\
\hline $\begin{array}{l}\text { 33. The answer to the study question is } \\
\text { given }\end{array}$ & $10(100)$ & $9(100)$ & 0.5 \\
\hline $\begin{array}{l}\text { 34. Conclusions follow from the data } \\
\text { reported }\end{array}$ & $10(100)$ & $9(100)$ & 0.5 \\
\hline $\begin{array}{l}\text { 35. Conclusions are accompanied by the } \\
\text { appropriate caveats }\end{array}$ & $10(80)$ & $9(100)$ & 0.23 \\
\hline
\end{tabular}

* Comparable estimates available from Pirraglia et al, 2004

${ }^{* *}$ Not Appropriate

Table 4. BMJ Checklist 


\section{Discussion}

To conclude, few are the economic evaluation studies, but not of apparent or significantly lower quality than that of conventional medicine. And that despite the fact that the majority of the studies of the conventional medicines selected are published in journals with high impact factor [71-79]. The majority of homeopathic studies are observational whereas randomization is generally accepted as the most objective manner to have comparable groups. It is known that we should not generally use observational data to establish or attribute a difference between therapies, but they can be used to estimate the economic consequences of such a difference [83]

Nevertheless, some observational studies under evaluation particularly addressed this problem and prove that their groups are comparable in basic medico-demographic characteristics [66,67]. Also, many of the conventional studies comprised in the BMJ criteria evaluation use modeling approaches and one of them is based exclusively on expert opinion [78] that is classified in the lowest degree in the hierarchy of evidence. This probably is one of the reasons why the majority of these studies use sensitivity analysis in contradiction to homeopathic studies as is the dominating method of handling uncertainty in modeling studies (being nevertheless complementary and not substitute of the handle of uncertainty in stochastic approaches).

The limitations of these reviews are similar to those of other reviews. First, the only one reader was not blinded to journals and article authors, possibly having influenced results. To maximize accuracy, data extraction was performed many times -at least twice for each paper. Second, the measures of study quality depend on the information reported in an article, and no attempt was made to judge the merits of clinical or modeling assumptions and model choice made in the analyses. Also, no quality criteria exist for the amount of missing data that in some studies of conventional medicine not only surpass $15 \%$ of the data [85] in some RCT but reach even 79\% in a specific study [59].Third, the number of reviewed studies was small. Nevertheless, to diminish the coservatiness of the statistical tests for type I error we have used Fisher's conditional mid- $p$ test. Finally, while the strategy for identification, review, was rigorous, it is possible that some studies meeting finally the criteria of this review were not included [86].

\section{Conclusions}

Homeopathy is used almost worldwide by an important number of patients. Among the countries that grant homeopathic therapies not of a lesser status we can site France, England, Germany, India, Baglandesh, the United States, Canada, Brazil, and many more . France, England, Germany also are the countries that seem to dominate in the research on the efficiency of homeopathy. Some governmental reports support the financing of homeopathy based on reviews or on quasi experimental studies, some others are extremely negative. The financing or not of the homeopathic therapies by a third payer has clear 
consequences on the budgets of thousand of citizens who use homeopathy and on the accessibility of these therapies by the more vulnerable social categories. Because of their popularity, governments should be busy with homeopathy more seriously as well as with the framework of homeopathy and what it entails, that is:

Firstly, Good Manufacturing Practices such as cleanrooms must be applied on homeopathic products in order to ensure their quality.

Also, the need of assessing these therapies so as to find out which is the exact extension that truly is beneficial to the state and society making their funding necessary.

The debate with regard to efficacy/effectiveness and efficiency of homeopathy has dominated the scene the last decades. On the other hand, the quality of homeopathic economic evaluation studies seems to constantly progress given that more recent studies are characterized by an improved design and more detailed reports, as is the case with conventional studies. The trial based economic evaluations comparing homeopathy with conventional medicine do not seem to be of lower quality than studies of conventional medicine and complete the majority of the ISPOR criteria. Also, there are not statistically significant differences between studies of conventional and homeopathic medicine based on BMJ quality criteria. Certainly, the need for further improvement of both 2 categories of studies is obvious. And the greatest problem with homeopathic studies is their limited number.Nevertheless, despite objections there emerge serious indications of effectiveness and efficiency concerning homeopathic therapies. Yet the health effect ought to be proven through further well designed randomized trials.

Crossover design that allows robust estimates of intraindividual consistency of response using placeo-control groups and allows for preference assessments of benefit/tolerability ratios seem to be appropriate in case of moderate chronic diseases (e.g. allergy, rhumatology).Also, extended cross over designs or $\mathrm{N}$ of 1 trials seem to be more appropriate in diseases where treatments even of conventional medicine are highly individualized (e.g autism).

The trade off between conventional and homeopathic medicine concerning participant eligibility criteria is another crucial point of organized trials with homeopathic medicines. The development of multiple large and more pragmatically oriented clinical trials would make it possible to make viable effectiveness comparisons between specific patient groups. Additionally, it will permit to compare the resulting benefit to the avoidance of side effects in the case of homeopathic medicines.

Also, the enrichment of the quality of life questionnaires comprising such items in order to measure the potential benefits of homeopathy as claimed by homeopaths, including stess and control management and life attitude will be very useful in that they helped surface the effects of homeopathic treatments in the well being of citizens. Only by taking into consideration all the specific parameters we may a arrive at strong conclusions for the efficiency of homeopathy. 
On a next stage the dimarginalization of homeopathy practitioners and the use of homeopathic treatments by all doctors in the fields where their efficiency would have been proven, would lead to optimization of medical practices for the benefit of society.

\section{Author details}

Vilelmine Carayanni

Technological Educational Institute of Athens, Greece

\section{Acknowledgement}

The author would like to thank Dr Spyros Diamantides and Dr Persa Kyvelou for her significant assistance in writing this paper.

\section{References}

[1] OECD , Health Data, OECD Editions ;2011

[2] Nahin, Richard et al. "Cost of Complementary and Alternative Medicine (CAM) and The Frequency of Visits to CAM practitioners: United States, 2007." National Health Statistics Report, $18: 4 ; 2009$.

[3] CAMDOC Alliance. The regulatory status of Complementary and Alternative Medicine for medical doctors in Europe, http://www.camdoc.eu/Pdf/CAMDOCRegulatoryStatus8_10.pdf (accessed 8 June 2012).

[4] Herman P, Craig B., Caspi O., Is complementary and alternative medicine (CAM) costeffective? a systematic review, Complementary and Alternative Medicine 2005;5-11.

[5] ECHAMP, The science of Homeopathy, http://www.alternative- training.com/docs/Blog/LUC_MONTAGNIER.pdf (accessed 8 February 2012)

[6] Benveniste, Jacques (2005) Ma vérité sur la 'mémoire de l'eau', Albin Michel; 2005.

[7] Official Homeopathy Resource, New Research From Aerospace Institute of the University of Stuttgart Scientifically Proves Water Memory and Homeopathy, http://homeopathyresource.wordpress.com/2011/12/28/new-research-from-aerospaceinstitute-of-the-university-of-stuttgart-scientifically-proves-water-memory-andhomeopathy/ (accessed 8 June 2012).

[8] Demangeat JL, Gries P, Poitevin B, Droesbeke JJ, Zahaf T, Maton F, Pierart C, Muller RN Low-field NMR water proton longitudinal relaxation in ultra-highly diluted aqueous solutions of silica-lactose prepared in glass material for pharmaceutical use. Appl Magn Reson 2004;26 465-481.

[9] Elia V, Niccoli M New physico-chemical properties of water induced by mechanical treatments. A calorimetric study at $25^{\circ} \mathrm{C}$. J Thermal Analysis Calorimetry 2000; $61527-$ 537. 
[10] Wolf U. et al. "Effectiveness, Safety and Cost Effectiveness of Homeopathy Practise" Forschende 2006;13.2:19-29.

[11] Linde K, Clausius N, Ramirez G, Melchart D, Eitel F, Hedges LV, Jonas WB Are the effects of homeopathy placebo effects? A meta-analysis of randomized, placebo controlled trials Lancet 1997350 834-843.

[12] Righetti m., Baumgartne S., Ammon k. Homeopathy: Research and Research Problems (preclinical and clinical) In: Bornhöft, Gudrun; Matthiessen, Peter (Ed) Homeopathy in Healthcare Effectiveness, Appropriateness, Safety, Costs. Springer; 2012. p16-22.

[13] Bastide M, Doucet-Jaboeuf M, Daurat V ( Action immunopharmacologique des preparations de thymus et $\mathrm{d}^{\prime}$ hormone thymique utilisees a doses infinitesimales. Homeopathie Francaise1983;71v 185-189.

[14] Endler PC, Ludtke R, Heckmann C, Zausner C, Lassnig H, Scherer-Pongratz W, Haidvogl M, Frass M Pretreatment with thyroxine (10-(8) parts by weight) enhances a 'curative' effect of homeopathically prepared thyroxine (10-(13)) on lowland frogs. Forschende Komplementarmedizin und Klassische Naturheilkunde 2003; 137-142.

[15] Youbicier-Simo BJ, Boudard F, Mekaouche M, Bayle JD, Bastide M A role for bursa fabricii and bursin in the ontogeny of the pineal biosynthetic activity in the chicken. J Pineal Res 1996;21:35-43.

[16] Bellavite P, Ortolani R, Conforti "Immunology and Homeopathy. 3. Experimental Studies on Animal Models, Evid Based Complement Alternat Med. 2006 ; 3(2) 171-186.

[17] Shang, A., Huwiler-Müntener K, Nartey L, Jüni P, Dörig S, Sterne JA, Pewsner D, Egger M. Are the clinical effects of homeopathy placebo effects? Comparative study of placebo-controlled trials of homeopathy and allopathy Lancet 2005; 366 726-732.

[18] Glaser, R Stress-associated immune dysregulation and its importance for human health: a personal history of psychoneuroimmunology' Brain, Behavior and Immunity 2005; 19 3-11.

[19] Lovallo, W.R. \& W. Gerin 'Psychophysiological reactivity: mechanisms and pathways to cardiovascular disease' Psychosomatic Medicine, 2003;65 36-45.

[20] Kienle, G.S. \& H. Kiene 'The powerful placebo effect: fact or fiction?' Journal of Clinical Epidemiology 1997; 50:1311-1318.

[21] European Network for Homeopathy Researchers (ENHRAn Overview of Positive Homeopathy Research and Surveys (http://hpathy.com/scientific-research/an-overviewof-positive (accessed 8 February 2012)

[22] Jonas W., Anderson R, Crawford C, Lyons J. A systematic review of the quality of homeopathic clinical trials BMC Complementary and Alternative Medicine 2001, 1-12.

[23] Tsang R, Colley L, Lynd LD J Clin Epidemiol. Inadequate statistical power to detect clinically significant differences in adverse event rates in randomized controlled trials. $2009 ; 62(6): 609-616$

[24] Hu JK, Chen ZX, Zhou ZG, Zhang B, Tian J, Chen JP, Wang L, Wang CH, Chen HY, Li YP Intravenous chemotherapy for resected gastric cancer: meta-analysis of randomized controlled trials. World J Gastroenterol 2002 ; 8(6) 1023-1028 
[25] Wassenhoven Van M. and Ives Geoffrey "An Observational Study of Patients Receiving Homeopathic Treatment" Homeopathy 2004; 93 3-11.

[26] Rossi E, Crudeli L, Endrizzi C. and Garibaldi D.“Cost-Benefit Evaluation of Homeopathy versus Conventional Therapy in Respiratory Diseases" Homeopathy 2009; 98 2-10.

[27] Ullman D. Homeopathic perspectives on infectious diseases, http://www.homeopathic.com/Articles/Using_homeopathy_for_ailments/A_Homeopat hic_Perspective_on_Infectious_Dise.html (accessed12 May 2012)

[28] Global TGI Barometer, TGI; 2008.

[29] Complementary Medicines - UK Mintel;2007.

[30] ECHAMP's Facts \& Figures, 2nd Ed ECHAMP; 2007

[31] Comparatif Mutuelle et Assurance Complémentaire Santé, L'homéopathie séduit de plus en plus de Français http://www.devismutuelle.com/article/267-1-homeopathieseduit-la-france (accessed 8 June 2012)

[32] British Homeopathic Association, Popularity and the market place, http://www.britishhomeopathic.org/media_centre/facts_about_homeopathy/popularity _and_market_place.html (accessed 12 May 2012)

[33] Bundesverband der Pharmazeutischen Industrie e.V., Pharma-Daten 2007 http://whqlibdoc.who.int/hq/2001/WHO_EDM_TRM_2001.2.pdf. (accessed 12-6-2012)

[34] Legal Status of Traditional Medicine and Complementary/Alternative Medicine: A Worldwide Review" (PDF). World Health Organization. World Health Organization; 2001.

[35] Dacey J (14 January 2011). "Alternative therapies are put to the test". swissinfo.ch. (accessed 12 July 2012)

[36] French Government Report: Social Security Statistics, CNAM (National InterRegulations System) 61;1991

[37] Bornhöft G, Wolf U, Ammon K, Righetti M, Maxion-Bergemann S, Baumgartner S, Thurneysen AE, Matthiessen PF. Effectiveness, safety and cost-effectiveness of homeopathy in general practice - summarized health technology assessment. Forsch Komplementärmed 2006;13(suppl 2) 19-29

[38] Centre fédéral d'expertise des soins de santé Etat des lieux de lieux de l'homéopathie en Belgique KCE reports 154B

https://kce.fgov.be/sites/default/files/page_documents/kce_154b_homeopathie_en_belgi que.pdf (accessed 7 February 2012)

[39] Marstedt G, Moebus S Gesundheitsberichterstattung des Bundes Heft 9: Inanspruchnahme alternative Methoden in der Medizin. 2002; Verlag Robert Koch Institut, Berlin

[40] House of Commons Science and Technology Committee Evidence Check 2: Homeopathy Fourth Report of Session 2009-10

http://www.publications.parliament.uk/pa/cm200910/cmselect/cmsctech/45/45.pdf

[41] DRAFT NHMRC Public Statement on Homeopathy 
http://images.theage.com.au/file/2012/03/14/3125800/Homeopathy\%2520statement.pdf (access d 8 May 2012)

[42] SANTE CANADA Programme de recherche sur les produits de santé naturels Table ronde sur invitation dans le cadre d'une consultation sur l'établissement des priorités de recherche en médecine http://www.hc-sc.gc.ca/dhp-mps/pubs/natur/2008nhprp_prpsn/index-fra.php (accessed 5 February 2012)

[43] Caisse Nationale de l'Assurance Maladie des Travailleurs Salaries, Rapport, 1996;CNAM

[44] Swayne, J. The cost and effectiveness of homeopathy. Br Homeopath J 1992; 81 148-150

[45] Smallhood C. The role of complementary and alternative medicine in the NHS http://www.getwelluk.com/uploadedFiles/Publications/SmallwoodReport.pdf (accesed 12 May 2012)

[46] Ramsey S, Willke R, Briggs A, Brown R, Buxton M, Chawla A,Cook J, Glick H, Liljas B, Petitti D, Reed S:Good research practicesfor cost-effectiveness analysis alongside clinical trials: theISPOR RCT-CEA Task Force report. Value Health 2005; 8 521-533

[47] Drummond MF, Jefferson TO, BMJ Economic Evaluation Working Party: Guidelines for authors and peer reviewers of economic submissions to the BMJ. BMJ 1996, 313:275-283.

[48] Polsky D, Doshi JA, Bauer MS, Glick HA. Clinical Trial-Based Cost-Effectiveness Analyses of Antipsychotic Use, Am J Psychiatry 2006;163:12.

[49] Paul A. Pirraglia, M.D., M.P.H.; Allison B. Rosen, M.D., M.P.H.; Richard C. Hermann, M.D., M.S.; Natalia V. Olchanski, M.S.; Peter Neumann, Sc.D. Cost-Utility Analysis Studies of Depression Management: A Systematic Review Am J Psychiatry 2004;161 2155-2162.

[50] Drummond MF, O'Brien B, Stoddart GL, Torrance GW: Methods for the economic evaluation of health care programmes .Second edition. Oxford, Oxford University Press; 1997:305.

[51] Center for Reviews and Dissemination http://www.york.ac.uk/inst/crd/index.htm (accessed 12 June 2012)

[52] Paterson C, Ewings P, Brazier J E, Britten N. Treating dyspepsia with acupuncture and homeopathy: reflections on a pilot study by researchers, practitioners and participants. Complementary Therapies in Medicine 2003; 11(2) 78-84 50.

[53] Kneis K C, Gandjour A Economic evaluation of Sinfrontal ${ }^{\circledR}$ in the treatment of acute maxillary sinusitis in adults, Applied Health Econ Health Policy 2009; 7 (3): 181-191.

[54] Thompson EA, Shaw A, Nichol J, Hollinghurst S, Henderson AJ, Thompson T, Sharp D.The feasibility of a pragmatic randomised controlled trial to compare usual care with usual care plus individualised homeopathy, in children requiring secondary care for asthma. Homeopathy 2011; 100(3): 122-130.

[55] Chouinard G et al. A Canadian multicenter placebo-controlled study of fixed doses of risperidone and haloperidol in the treatment of chronic schizophrenic patients. Journal of Clinical Psychopharmacology 1993;13:25-40. 
[56] Tunis S L, Johnstone B M, Gibson P J, Loosbrock D L, Dulisse B K. Changes in perceived health and functioning as a cost-effectiveness measure for olanzapine versus haloperidol treatment of schizophrenia. Journal of Clinical Psychiatry 1999; 60(Supplement 19): 38-45.

[57] Rosenheck R, Cramer J, Xu W, Grabowski J, Douyon R, Thomas J, Henderson W, Charney D. Multiple outcome assessment in a study of the cost-effectiveness of clozapine in the treatment of refractory schizophrenia. Health Services Research 1998; 33(5) 1237-1267.

[58] Rosenheck R, Cramer J, Allan E, Erdos J, Frisman L K, Xu W C, Thomas J, Henderson $\mathrm{W}$, Charney D. Cost-effectiveness of clozapine in patients with high and low levels of hospital use. Archives of General Psychiatry 1999; 56(6) 565-572.

[59] Hamilton S H, Revicki D A, Edgell E T, Genduso L A, Tollefson G. Clinical and economic outcomes of olanzapine compared with haloperidol for schizophrenia: results from a randomised clinical trial. Pharmacoeconomics 1999; 15(5) 469-480.

[60] Essock S M, Frisman L K, Covell N H, Hargreaves W A. Cost-effectiveness of clozapine compared with conventional antipsychotic medication for patients in state hospitals. Archives of General Psychiatry 2000; 57(10) 987-994.

[61] Jerrell J M. Cost-effectiveness of risperidone, olanzapine, and conventional antipsychotic medications. Schizophrenia Bulletin 2002; 28(4) 589-605.

[62] Rosenheck R, Perlick D, Bingham S et al, Effectiveness and cost of olanzapine and haloperidol in the treatment of schizophrenia: a randomized controlled trial. JAMA 2003; 290(20) 2693-2670.

[63] Thorpe KE, Zwarenstein M, Oxman AD, et al. A pragmatic-explanatory continuum indicator summary (PRECIS): a tool to help trial designers. J Clin Epidemiol 2009; 62 464-75.

[64] Carayanni V, and Tsati E: Explanatory versus pragmatic trial-based economic evaluations: application to alternative therapies for burns Expert Rev. Pharmacoeconomics Outcomes Res. 2010; 10(1) 37-48

[65] CONSORT 2010 Statement: updated guidelines for reporting parallel group randomised trials BMJ 2010;340 available at: http://www.bmj.com/content/340/bmj.c332.full (accessed 23 Mars 2010).

[66] Stagnara J., Demonceaux A., Vainchtock A., Nicoloyannis N., Duru G. Etude sur la prise en charge de la bronchiolite du nourrisson en médecine ambulatoire. Etude observationnelle prospective à propos de 520 patients. Le Pédiatre 2004; (204),1-7

[67] Vainchtock A., Dansette G.Y., Nicoloyannis N., Duru G., Chaufferin G., Lamarsalla L. Medico economic evaluation of anxiety disorders management in outpatient care. Health and System Science 2000; 4 103-115.

[68] Trichard M, Chaufferin G, Nicoloyannis N. Pharmacoeconomic comparison between homeopathic and antibiotic treatment strategies in recurrent acute rhinopharyngitis in children. Homeopathy 2005 94(1):3-9. 
[69] Witt C, Keil T, Selim D, Roll S, Vance W, Wegscheider K, Willich SN. Outcome and costs of homoeopathic and conventional treatment strategies: A comparative cohort study in patients with chronic disorders. Complementary Therapies in Medicine 2005; $13,79-86$

[70] Witt C M, Brinkhaus B, Pach D, Reinhold T, Wruck K, Roll S, Jäckel T, Staab D, Wegscheider K, Willich S N Homoeopathic versus conventional therapy for atopic eczema in children: medical and economic results, Dermatology 2009; 219 (4) 329-340.

[71] Revicki DA, Brown RE, Palmer W, Bakish D, Rosser WW, Anton SF, Feeny D: Modelling the cost effectiveness of antidepressant treatment in primary care. Pharmacoeconomics 1995; 8524-540

[72] Lave J R, Frank R G, Schulberg H C, Kamlet M Cost-effectiveness of treatments for major depression in primary care practice. Archives of General Psychiatry 1998; 55(7) 645-651

[73] Schoenbaum M, Unutzer J, Sherbourne C, Duan N, Rubenstein L V, Miranda J, Meredith L S, Carney M F, Wells K. Cost-effectiveness of practice-initiated quality improvement for depression. JAMA 2001; 286(11) 1325-1330

[74] Valenstein M, Vijan S, Zeber J E, Boehm K, Buttar A. The cost-utility of screening for depression in primary care. Annals of Internal Medicine 2001; 134(5) 345-360

[75] Kamlet M S, Paul N, Greenhouse J, Kupfer D, Frank E, Wade M. Cost utility analysis of maintenance treatment for recurrent depression. Controlled Clinical Trials 1995; 16 1740.

[76] Gournay K, Brooking J. The community psychiatric nurse in primary care: an economic analysis. Journal of Advanced Nursing 1995; 22 769-778.

[77] Revicki D A, Brown R E, Keller M B, Gonzales J, Culpepper L, Hales R E. Costeffectiveness of newer antidepressants compared with tricyclic antidepressants in managed care settings. Journal of Clinical Psychiatry 1997; 58(2) 47-58.

[78] Hatziandreu E J, Brown R E, Revicki D A, Turner R, Martindale J, Levine S, Siegel J E. Cost utility of maintenance treatment of recurrent depression with sertraline versus episodic treatment with dothiepin. Pharmacoeconomics 1994; 5(3) 249-264.

[79] Nuijten MJ: Assessment of clinical guidelines for continuation treatment in major depression. Value Health 2001; 4 281-294.

[80] Agresti A. Categorical Data Analysis (2nd edn). Wiley: Hoboken, NJ;2002

[81] Moher D, Liberati A, Tetzlaff J, Altman DG, The PRISMA Group Preferred Reporting Items for Systematic Reviews and Meta-Analyses: The PRISMA Statement. PLoS Med 6(6): e1000097 2009; doi:10.1371/journal.pmed1000097

[82] MF Drummond. Experimental versus Observational Data in the Economic Evaluation of Pharmaceuticals. Med. Decis. Making 1998; 18 (S12 - S18)

[83] Shemilt I., Mugford M., Vale Luke, Kevin Marsh, Donaldson C., Evidence -Based Decisions and Economics. Health Care, Social Welfare, Education and Criminal Justice, Second Edition, BMJI Books, Wiley-Blackwell;2010. 
[84] Piantadosi S. Clinical trials, a methodological perspective, $2^{\text {nd }}$ Edition, Wiley Series in Probability and Statistics, Wiley; 2006.

[85] Fragkakis M. and Alexandris N. Outline of a trust and security model for multi-agent system platforms Advances in Computer Science and Engineering 2010; 6(1), 57 - 71 